\section{Hydrosol definition crucial}

When is a hydrosol not a hydrosol? When it is formed within the body, according to a recent court judgment on Novartis's claimed patent infringement against generic drugs company Eon. Novartis Pharmaceuticals has used its patented hydrosol formulation to administer the poorly soluble immunosuppressant drug cyclosporin in a readily absorbable aqueous form. Novartis's US patent 5,389,382 explains that a hydrosol formulation can be prepared by dissolving the drug in a water-miscible solvent and then adding a comparatively large amount of water to that solution. The result is an aqueous dispersion of very small solid drug particles that are more readily absorbed.

Eon makes capsules that contain cyclosporin suspended in ethanol, without the presence of water. Although Novartis accepts that Eon does not sell cyclosporin in the form of a hydrosol, it argued that when one of Eon's capsules is ingested, an infringing hydrosol is formed with the aqueous environment of the patient's stomach, and that Novartis's patent is infringed literally, as well as under the doctrine of equivalents (DOE) argument.

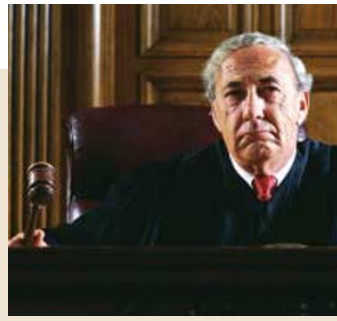

The two-judge majority looked at several dictionaries, first with regard to the meaning of 'hydrosol', and also 'solution' and 'medicinal'. The court agreed with the judgement of the Delaware district court that claim interpretation of 'hydrosol' did not include formation of the hydrosol in a patient's stomach after ingestion of a cyclosporin capsule. Both the specification, which repeatedly referred to the hydrosol as a 'pharmaceutical composition', and the prosecution history supported the court's interpretation. The DOE argument was also rejected because of the claimed requirement that the dispersion be prepared outside the body.

In dissent, Judge Clevenger argued that the majority had overworked the use of the dictionary to the point of error and that Federal Circuit case law has long recognized that medicines claimed in patents can be made inside or outside the body; infringement will occur in either case if the proper proofs are made.

Novartis versus Eon Labs: http://www.fedcir.gov/opinions/03-1211.doc

\section{Apotex wins latest round in generic Paxil litigation}

In the ongoing litigation over Apotex's generic version of GlaxoSmithKline's (GSK)

antidepressant paroxetine hydrochloride (Paxil), the US Federal Circuit Appeals Court has reversed the previous patent infringement ruling of the district court against Apotex, but at the same time has found GSK's US patent 4,721,723 invalid, thereby ultimately handing a victory to Apotex.

In the 1970s, paroxetine hydrochloride (PHC) anhydrates were invented in the UK and, in 1998, a PHC hemihydrate compound was patented by GSK (then SmithKline Beecham) and marketed as Paxil. In 1998, Apotex submitted an Abbreviated New Drug Application to the US FDA to market an antidepressant based on the anhydrate form of PHC, and filed a certification that its proposed product would not infringe GSK's '723 patent for the PHC hemihydrate product. However, GSK claimed that Apotex's anhydrate version naturally converts into the hemihydrate version, making it likely that there would be some hemihydrate in Apotex's product, therefore infringing the ' 723 patent. Although the district court interpreted the claim as requiring the presence of commercially significant amounts of the hemihydrate for infringement to take place, the Federal Court found no reason to limit the scope in such a way.
The public use of an invention more than one year prior to its patent application date prevents the inventor from obtaining a US patent. However, the doctrine of experimental use allows an inventor to engage in activities that would otherwise fall under the public use bar. Judge Rader, for the majority, found that patent '723 was invalid because clinical trials occurred more than one year prior to filing; furthermore, the experimental use exemption did not apply in this case because the trials tested only the safety and efficacy of PHC hemihydrate as an antidepressant rather than experimental use of the chemical compound as claimed in claim 1 .

SmithKline Beecham versus Apotex

http://www.fedcir.gov/opinions/03-1285.doc

\section{Housey loses patents}

In an infringement suit against a number of large pharmaceutical companies concerning Housey Pharmaceutical's four patents for methods of screening, the US Court of Appeals for the Federal Circuit affirmed the decision of the District Court by a majority of two to one, leading to a judgement of invalidity of the patents. The crux of the case hinged on claim construction - the definition of an inhibitor or activator of a protein'.

Previously, the district court conducted a Markman hearing to interpret the claims of the Housey patents. A Markman hearing, typically conducted pre-trial, is when the trial judge hears evidence about the meaning of the asserted patent claim, and then makes a judgement as a matter of law. A narrow claim interpretation can often favour accused infringers because it can allow them to escape literal infringement. On the other hand, the wider the interpretation, the more probable it is that infringers will fall within the claim's limitations. Too broad a claim interpretation, however, can create problems for the patentee by causing the patent claim to be invalid in light of the prior art. Because the meaning of the claims is often central to deciding the case, Markman hearings reduce the number of patent cases that are tried by a jury.

During the hearing, Housey argued for a narrow interpretation, that an 'inhibitor or activator of a protein' was limited to substances that directly interact with - that is, bind to - the target protein. However, the Federal Circuit held that the definition included substances that both directly and indirectly affect a protein of interest, and the patent and its prosecution history clearly supported the broad plain meaning.

In dissent, Judge Newman criticized her colleagues for relying on plain and ordinary dictionary definitions of common words in connection with claimed subject matter without due consideration of the context of the invention. She would have remanded the case to the District Court to resolve allegedly conflicting scientific evidence and construction of the claim in light of that evidence.

Housey Pharmaceutical Inc. versus Astrazeneca UK Ltd. http://www.fedcir.gov/opinions/03-1193.doc 